\title{
Specialista vzorkování vod a požadavky na jeho odbornou způsobilost
}

\section{JIŘí KUČERA, JANA ČAPKOVÁ, ALŽBĚTA PETRÁNOVÁ, PETR A. SKŘEHOT, MARCELA SKŘEHOTOVÁ}

Klíčová slova: odběr vzorků - vzorkař - kvalifikace

\section{SOUHRN}

Za odběr vzorků pro účely stanovené vodním zákonem, zákonem o vodovodech a kanalizacích a zákonem o ochraně veřejného zdraví zodpovídá zkušební laboratoř. Požadavky na kvalifikaci a další vzdělávání vzorkařů definuje laboratoř ve své rízené dokumentaci, přičemž v oblasti vzorkování vod jsou nově minimální požadavky stanoveny v normě ČSN EN ISO 5667-14. K definování požadavků může laboratoř využít kvalifikační standardy pro povolání vzorkař pitných vod a vzorkař odpadních vod. V př́spěvku jsou popsány důvody vedoucí k navržení nového povolání specialista vzorkování vod a jeho kvalifikačního standardu. Zároveň jsou predstaveny dokumenty zpracované k problematice bezpečnosti a ochrany zdraví při práci pro oblast vzorkování vod.

\section{ÚVOD}

Zpracování programu odběru vzorků a následné precizní provedení vlastního odběru předurčují, nakolik bude výsledek navazujícího rozboru použitelný k účelu, pro nějž byl pořízen. To se týká i vzorkování vod, at již v oblasti výzkumu, či při kontrole dodržování požadavků právních předpisů - míry znečištění povrchových a podzemních vod, kvality pitné vody či znečištění odpadních vod. Pokud jde o vzorkování předepsané právními předpisy, je jednoznačné, že za kvalitu odběru vzorku odpovídají laboratoře, které musí být akreditovány od Českého institutu pro akreditaci, o. p. S., držiteli osvědčení o správné činnosti laboratoře vystaveného ASLAB, autorizovány Státním zdravotním ústavem, př́ipadně autorizovány podle zákona o metrologii (jednotlivé předpisy upravují požadavky na prokázání odborné způsobilosti laboratoří poněkud odchylně). Předpisy dále uvádějí řadu technických požadavků, z nichž některé v zásadě definují program odběru vzorků, ale nejsou stanoveny žádné zvláštní požadavky na způsobilost osob oprávněných ke vzorkování vod v rámci laboratoře - vzorkařŭ. Požadavky na odbornou způsobilost všech osob pracujících v laboratoři včetně vzorkařu a osob organizujících vzorkování definuje v souladu s normou ČSN EN ISO/IEC 17025 [1] sama laboratoř a o vhodnosti zvolených požadavků musí presvědčit akreditační či jiný dozorový orgán.

Autoři článku se v rámci projektu podpořeného Technologickou agenturou ČR a řešeného v letech 2016 a 2017 zabývají problematikou požadavků na kvalifikaci vzorkařů s cílem zpracovat doporučení k vhodné úrovni kvalifikace, kterou by mohly laboratoře využít při své činnosti. Významná pozornost je věnována nejen odborné způsobilosti k odběru vzorků, ale rovněž zajištění bezpečnosti a ochrany zdraví při práci.

\section{SOUHRN POŽADAVKŮ NA ČINNOST VZORKAŘE A JEHO KVALIFIKACI}

Odběr vzorků vod pro účely definované právními predpisy se řídí těmito předpisy. Jde zejména o vodní zákon [2] (stav povrchových a podzemních vod, míra znečištění vypouštěných odpadních vod), zákon o vodovodech a kanalizacích [3] (upravovaná a pitná voda v procesu výroby a odpadní voda v kanalizaci a v procesu čištění) a zákonem o ochraně veřejného zdraví [4] (pitná voda u spotřebitele a povrchové vody užívané ke koupání) a jejich prováděcí předpisy [5]. Upraveny jsou četnost odběru vzorků, typ vzorků, způsob předúpravy, požadované rozbory a další technické aspekty, takže tyto předpisy do značné míry předurčují program odběru vzorků zpracovaný laboratoří.

Neméně důležité jsou požadavky na bezpečnost práce a prevenci rizik stanovené zákoníkem práce [6], zákonem o zajištění dalších podmínek bezpečnosti a ochrany zdraví při práci [7] a jeho prováděcími předpisy [8]. Bezpečnostní aspekty, které se $k$ práci vzorkaře váží, nejsou v těchto predpisech podrobněji řešeny, a proto bylo třeba vycházet z analogií pro príbuzné obory činností a zkušeností z aplikační praxe. Vzorkař se musí dále orientovat $v$ predpisech upravujících pohyb v různých typech chráněných území a ochranných pásem.

Základní požadavky na kvalifikaci vzorkařů vycházejí z normy ČSN EN ISO/IEC 17025 [1] a jsou uvedeny v kapitole 5.2 společně pro všechny osoby pracující v laboratoři včetně vzorkařů. Úroveň požadavků si stanoví laboratoř s ohledem na rozsah vykonávaných činností a tuto úroveň poté obhajuje před akreditačním orgánem.

Postupy pro odběry vzorků vod včetně prípravy programů odběru vzorků (jindy zvaných též plány vzorkování), konzervace vzorků a zabezpečování kvality jsou upraveny v technických normách řady ČSN EN ISO 5667. V březnu 2017 vyšla aktualizace normy ČSN EN ISO 5667-14 Kvalita vod - Odběr vzorků Část 14: Návod pro prokazování a řízení kvality odběru vzorků vod a manipulace s nimi [9], která nově definuje speciální požadavky na výcvik vzorkařu. Požadováno je vhodné vzdělání, počáteční odborný výcvik, pravidelné školení a prověřování výkonnosti vzorkařŭ. Tyto nové požadavky se do běžné praxe budou teprve postupně promítat.

\section{SOUČASNÁ PRAXE LABORATOŘÍ V POŽADAVCÍCH NA KVALIFIKACI VZORKAŘE}

V rámci řešení projektu bylo provedeno dotazníkové šetření mezi vzorkaři firem provádějících vzorkování vod a akreditovaných laboratoří zaměřený na kvalifikační požadavky kladené na vzorkaře a na praktické otázky související s bezpečností práce při vzorkování vod. Byly získány odpovědi od 168 respondentů. $\checkmark$ rámci průzkumu nebyl omezen počet respondentů $z$ jedné laboratoře či 
firmy, počet odpovědí určitého typu proto nevypovídá zcela presně o počtu pracovišt se stejným přístupem ke kvalifikaci a vzdělávání vzorkařù. Výsledky však poskytují dobrou celkovou představu o používaných požadavcích.

Jednotlivé laboratoře požadují podle respondentů v 74 prípadech nejméně střední nebo střední odborné vzdělání bez maturity, v 81 prípadech úplné střední s maturitou, ve čtyřech prípadech vyšší odborné nebo vysokoškolské bakalářské a v jednom prípadě vysokoškolské magisterské vzdělání.

Z šetření dále vyplývá, že délka požadované praxe u nastupujícího vzorkaře se pohybuje od žádné až po tři roky praxe (tato nejvyšší hodnota se objevila v 29 odpovědích). Respondenti obvykle kladli větší důraz na kvalitu vstupního školení a výcviku než na předchozí praxi.

Před zařazením pracovníka na pozici vzorkaře vod vyžadují laboratoře interní zaškolení vedoucím nebo manažerem v 75 případech, externí školení nebo seminář ve 33 prípadech a externí kurz zakončený zkouškou a vydáním osvědčení ve 47 prípadech.

Podle 22 odpovědí laboratoře nevyžaduji pravidelné školení vzorkařů. Čtyři respondenti uvádějí školení jednou za půl roku, 41 jednou ročně, 33 jednou za dva roky, 25 jednou za tři roky a 10 jednou za pět let. $V$ řadě odpovědí byla rozlišena větší četnost interních školení a méně častá účast na externích kurzech.

\section{ÚVAHY O ÚROVNI KVALIFIKACE A VZDĚLÁVÁNÍ V LABORATOŘI}

Jak již bylo uvedeno, požadavky na kvalifikaci, výcvik a prověřování znalostí vzorkařư nově stanoví norma ČSN EN ISO 5667-14. Jde o minimální standard, který budou muset zavést všechny laboratoře, poskytuje však dostatek volnosti k tomu, aby laboratoře přizpůsobily postupy podle svých potřeb a zaměření. Je zřejmé, že vzorkaři „provozní laboratoře zabývající se pouze rozbory vyráběné pitné vody a čištěné a vypouštěné odpadní vody musí perfektně ovládat problematiku vzorkování pitných a odpadních vod, naproti tomu se nemusí detailněji orientovat $v$ problematice napríklad odběru podzemních vod. Vzorkaři laboratoře zaměřené na různé výzkumné projekty pak musí počítat s tím, že budou vzorkovat ve velmi rozdílných situacích a k různým účelưm a že často budou reagovat na místě na zjištění řešitele projektu (zadavatele práce).

Ze zkušeností praxe vyplývá, že je vhodné rozlišit dvě úrovně kvalifikace vzorkarŭ

Jednu úroveň představuje pracovník, který zajištuje odběry určitých typů vod víceméně rutinně stálými postupy. Takový vzorkař musí znát standardní operační postupy pro dané odběry a príslušné programy odběru vzorků a měl by být schopen na základě svých zkušeností identifikovat neobvyklé situace, vyhodnotit (sám nebo ve spolupráci s jiným vzorkařem) jejich dopady na kvalitu odběru vzorků a vypovídací schopnost odebraného vzorku a príjmout na místě potřebná opatření (podle situace posun bodu odběru, detailní zaznamenání okolností odběru apod.).

Za vyšší úroveň kvalifikace považujeme pracovníka, který je schopen nejen rádně provést odběr vzorků, ale tuto činnost také organizovat a řídit. Od takového pracovníka předpokládáme pochopení cílů, k nimž má vzorkování vést, a navržení tomu odpovídajícího programu odběru vzorků. Tento pracovník musí znát nejen vlastní postupy odběru vzorků, ale musí chápat i širší souvislosti fungování celého vzorkovaného systému. Pozice proto vyžaduje vyšší vzdělání a soustavné zvyšování kvalifikace.

Zatímco u "rutinních" pracovníků Ize za dostatečné považovat periodicky opakované interní školení v rámci laboratoře, u pracovníků rídících vzorkování je plně na místě další vzdělávání včetně externích kurzů.
Externí kurzy nabízejí komerčně různí poskytovatelé. Liší se délkou, odborným zaměřením (přehled problematiky nebo zaměření jen na určité druhy matric) i způsobem ukončení. Někdy je vydáváno potvrzení o absolvování kurzu, jindy je součástí kurzu závěrečná zkouška. Organizátoři kurzů nepotřebují žádné zaštítění jinou autoritou (certifikaci či autorizaci kurzu), úroveň kurzu je obvykle garantována dobrou pověstí organizátora a vystupujících lektorů.

Současné předpisy nepožadují prokazování kvalifikace vzorkařů nezávislým prezkoušením. Přesto je zaveden personální certifikát Manažer vzorkování vod, který můžeme považovat za vhodný způsob prokázání kvalifikace laboratoře vůči zákazníkům nad rámec její akreditace. Složení zkoušek a získání personálního certifikátu Ize chápat jako další, třetí úroveň kvalifikace vzorkařů v laboratoři. Instituce udílející personální certifikát jsou akreditovány Českým institutem pro akreditaci, o. p. s., a je tak zajištěna návaznost tohoto certifikátu na definované postupy.

\section{DEFINOVÁNÍ KVALIFIKAČNÍCH POŽADAVKU゚ NA VZORKAŘE}

Metodika, která je navrhována $v$ rámci řešení projektu, by měla poskytnout laboratorím vodítko k nastavení kvalifikačních požadavků na své vzorkaře.

Přestože nejspíše nejsou v praxi zcela běžně užívány ( $z$ výše uvedeného dotazníkového šetření mezi vzorkaři vyplynulo, že celých $79 \%$ oslovených respondentů je vůbec nepoužívá nebo o nich neví), existují veřejně dostupné databáze Národní soustava povolání (dále jen NSP; dostupná na webovém portále www.nsp.cz) a Národní soustava kvalifikací (dále jen NSK; dostupná na www.narodnikvalifikace.cz).

Národní soustava povolání je soustavně rozvíjený a na internetu dostupný katalog popisů povolání. Tvorba a aktualizace NSP je definovaná v § 6 zákona Č. 435/2004 Sb., o zaměstnanosti, ve znění pozdějších předpisů. NSP je nástrojem pro zvýšení mobility pracovní síly na základě potřeb trhu práce, které identifikuji zaměstnavatelé a odborníci z trhu práce. $V$ této databázi jsou evidovány i tři pozice vztahující se k problematice vzorkování vod, a to vzorkař pitných vod (ID 102061), vzorkař odpadních vod (ID 102060) a chemik pro vzorkování (ID 102812), včetně definování náplně práce. Vzorkař pitné vody provádí odběr vzorků pitné a surové vody na odběrných místech vodovodních řadů, zdrojů a úpraven vod. Vzorkař odpadních vod provádí odběr vzorků odpadních vod a kalů na odběrných místech kanalizace a čistíren odpadních vod. Chemik pro vzorkování provádí práce spojené s odběrem vzorků různých matric pro chemické a biologické analýzy a zajištuje předání do laboratoře. Ačkoliv jsou první dvě uvedená povolání v NSP rozdělena, v praxi dochází při vzorkování vod k jejich prolínání a vzorkař v mnoha případech odebírá vzorky pitných i odpadních vod.

Základní kvalifikační předpoklady pro povolání vzorkař pitných vod a vzorkař odpadních vod jsou v NSP téměř identické a liší se pouze v detailu. Obecně Ize říct, že podle NSP poskytuje nejvhodnější prípravu pro tuto pozici střední vzdělání s maturitní zkouškou, prípadně vyšší vzdělání v tomto nebo príbuzném oboru. Podle potřeby zaměstnavatele je kvalifikace vzorkařů doplněna o znalosti, které Ize získat absolvováním specializovaných kurzů. Poněkud odlišná je situace u chemika pro vzorkování. U této profese se na jednu stranu očekává jeho využití pro rutinní vzorkování především ve výrobních provozech, nicméně požadavky kladené na jeho znalosti a dovednosti jsou výrazně vyšší než v případech vzorkařů (pitné vody, resp. odpadních vod), nebot se předpokládá, že tento pracovník bude zpracovávat program odběru vzorků a podílet se na řizení procesu odběru vzorků včetně jejich transportu do laboratoří.

Detailnějším popisem a úrovní kvalifikace se zabývá Národní soustava kvalifikací. NSK je průběžně budovaný, státem podporovaný a občany i zaměstnavateli využitelný registr profesních kvalifikací existujicích na pracovním trhu v ČR. Umožňuje zájemcům získat celostátně uznávané osvědčení o jejich profesní 
kvalifikaci. Rozvoj a implementaci Národní soustavy kvalifikací zajištuje do roku 2015 stejnojmenný projekt MŠMT financovaný Evropským sociálním fondem a státním rozpočtem ČR.

Databáze NSK uvádí kvalifikační předpoklady pro obě dvě pracovní pozice vztahující se k problematice vzorkování vod, tj. vzorkař odpadních vod (kód 36-078-H) a vzorkař pitné vody (kód 36-079-H). Databáze uvádí, jaké kvalifikační standardy musí osoba splňovat pro jednotlivé profese, jakým způsobem má být realizována zkouška způsobilosti, dále pak požadavky na odbornou způsobilost zkoušejících a v neposlední řadě samotné hodnocení zkoušky a nezbytné materiální a technické vybavení pro provedení zkoušky.

Požadavky uvedené pro povolání vzorkař pitných vod a vzorkař odpadních vod Ize považovat za vhodnou, doporučenou úroveň kvalifikace vzorkařŭ. Pro potřeby laboratoří zajištujujicích odběru vzorků i jiných typů vod Ize tyto požadavky vhodně modifikovat a přizpůsobit konkrétním podmínkám. V NSK jsou požadavky definovány v zásadě jako podklady pro složení zkoušky, jako zadání zkušebních okruhů a otázek. V praxi k nim však Ize přistoupit jako k souhrnu potřebných znalostí a dovedností a využít je tímto zpưsobem.

Ačkoli povolání chemik pro vzorkování lze vnímat jako profesi s vyšší úrovní znalostí, než je vyžadována pro „běžné vzorkarěe, požadavky na toto povolání definované v NSK nelze volně aplikovat do oblasti vzorkování vod. V rámci metodiky, která bude výstupem projektu, je proto navrhováno povolání specialista vzorkování vod, které představuje alternativu povolání chemik pro vzorkování, nicméně se jedná o profesní specializaci. Kvalifikační standard specialisty vzorkování vod (tj. požadavky na jeho znalosti a dovednosti) byly navrženy tak, aby pracovník uměl nejen odebrat vzorek různých typů vod, ale aby uměl také zpracovat program odběru vzorků a další dokumentaci a řídit činnosti při vzorkování. Kvalifikační standard je koncipován ve stejné struktuře jako v NSK a i v tomto prípadě platí stejné poznámky o využití požadavků pro potřeby laboratoře jako u vzorkaře pitné vody nebo vzorkaře odpadních vod. Klíčovým inovativním prvkem ale je, že jednotlivá znalostní kritéria byla navržena na základě požadavků a potřeb aplikační sféry (viz provedené dotazníkové šetrení) a dalších skutečností získaných při aplikovaném výzkumu (např. provedené série terénních experimentů).

Jelikož nebude usilováno o zařazení této specializace do NSK, bude moci aplikační sféra navrženou metodiku využít zcela volně v rozsahu a způsobem podle svých představ. Metodickou podporou pro implementaci metodiky do praxe pak budou představovat zejména její př́lohy - metodické listy a obrazové prílohy, karta bezpečnosti a ochrany zdraví při práci, vzorový př́kaz k provedení odběru vzorků apod.

\section{METODICKÉ LISTY PRO ODBĚR VZORKU゚ VOD A DALŠÍ DOKUMENTY TÝKAJÍCÍ SE BEZPEČNOSTI PRÁCE PŘI VZORKOVÁNÍ}

Protože požadavky na odběry vzorků včetně předpisů bezpečnosti práce jsou rozptýleny $v$ řadě dokumentů, byly $v$ rámci řešení projektu zpracovány metodické listy pro odběr vzorků vod, které obsahují základní zásady pro odběr vzorků (pro orientaci v problematice, nikoliv pro raádné provedení odběru ve všech detailech), přehled právních předpisů upravujících odběr vzorků a bezpečnost a ochranu zdraví při práci, přehled norem pro odběr vzorků vod, seznam pomůcek, vybavení a dokumentace potřebných při práci, výčet možných nebezpečných situací a seznam osobních ochranných pracovních prostředků. Metodické listy byly zpracovány pro odběr vzorků tekoucích povrchových vod, stojatých povrchových vod, podzemních vod, pitných vod a odpadních vod včetně tekutých kalů (aktivovaného kalu apod.).
Části metodických listů týkající se bezpečnosti a ochrany zdraví při práci jsou provázány s kartou BOZP pro profesi vzorkař vod a tekutých kalů a vzorem př́kazu k provedení odběru vzorků. Využití těchto dokumentů pomůže laboratořím ke zvládnutí problematiky BOZP při odběrech vzorků vod. Finální verze metodiky včetně uvedených príloh, bude $v$ plném znění zveřejněna na webových stránkách řešitelských organizací na začátku roku 2018.

\section{Poděkování}

Přispěvek vznikl v rámci řešeni projektu TD03000017 Kritéria a požadavky na způsobilost osob oprávněných ke vzorkování vod. Projekt byl realizován za finančni podpory Technologické agentury České republiky.

\section{Literatura}

[1] ČSN EN ISO/IEC 17025:2005 Posuzování shody - Všeobecné požadavky na způsobilost zkušebních a kalibračních laboratoři

[2] Zákon č. 254/2001 Sb., o vodách a o změně některých zákonů (vodní zákon), ve znění pozdějších predpisů.

[3] Zákon č. 274/2001 Sb., o vodovodech a kanalizacích pro veřejnou potřebu a o změně některých zákonů (zákon o vodovodech a kanalizacích), ve znění pozdějších předpisů.

[4] Zákon č. 258/2000 Sb., o ochraně veřejného zdraví a o změně některých souvisejících zákonů, ve znění pozdějších predpisů.

\section{[5] Zejména tyto předpisy:}

Nařízení vlády č. 143/2012 Sb., o postupu pro určování znečištění odpadních vod, prováděni odečtư množství znečištění a měření objemu vypouštěných odpadních vod do povrchových vod.

- Nařízení vlády č. 401/2015 Sb., o ukazatelích a hodnotách prípustného znečištění povrchových vod a odpadních vod, náležitostech povolení k vypouštění odpadních vod do vod povrchových a do kanalizací a o citlivých oblastech.

- Nařizení vlády č. 57/2016 Sb., o ukazatelích a hodnotách přípustného znečištění odpadních vod a náležitostech povolení k vypouštění odpadních vod do vod podzemních.

- Vyhláška č. 428/2001 Sb., kterou se provádí zákon č. 274/2001 Sb., o vodovodech a kanalizacích pro veřejnou potřebu a o změně některých zákonů (zákon o vodovodech a kanalizacích), ve znění pozdèjších predpisů.

- Vyhláška č. 252/2004 Sb., kterou se stanoví hygienické požadavky na pitnou a teplou vodu a četnost a rozsah kontroly pitné vody, ve znění pozdějších předpisů.

- Vyhláška č. 5/2011 Sb., o vymezení hydrogeologických rajónů a útvarů podzemních vod, způsobu hodnocení stavu podzemních vod a náležitostech programů zjištování a hodnocení stavu podzemních vod, ve znění pozdějších předpisů.

- Vyhláška č. 98/2011 Sb., o způsobu hodnocení stavu útvarů povrchových vod, způsobu hodnocení ekologického potenciálu silně ovlivněných a umělých útvarư povrchových vod a náležitostech programů zjištování a hodnocení stavu povrchových vod, ve znění pozdějších předpisů.

Vyhláška č. 238/2011 Sb., o stanovení hygienických požadavků na koupaliště, sauny a hygienické limity písku v pískovištích venkovních hracích ploch, ve znění pozdějších předpisů.

- Vyhláška č. 123/2012 Sb., o poplatcích za vypouštění odpadních vod do vod povrchových.

[6] Zákon č. 262/2006 Sb., zákoník práce, ve znění pozdějších předpisů.

[7] Zákon č. 309/2006 Sb., o zajištění dalších podmínek bezpečnosti a ochrany zdraví prí práci, ve znění pozdějších předpisů.

[8] Zejména tyto předpisy:

Nařízení vlády č. 101/2005 Sb. o podrobnějších požadavcích na pracoviště a pracovní prostředí.

Nařizení vlády č. 362/2005 Sb., o bližších požadavcích na bezpečnost a ochranu zdraví při práci na pracovištích s nebezpečím pádu z výšky nebo do hloubky, ve znění pozdějších předpisů.

- Nařizení vlády č. 591/2006 Sb., o bližších minimálních požadavcích na bezpečnost a ochranu zdraví při práci na staveništích

- Nařízení vlády č. 361/2007 Sb., kterým se stanoví podmínky ochrany zdraví při práci, ve znění pozdějších předpisů

[9] ČSN EN ISO 5667-14:2017 Kvalita vod - Odběr vzorků - Část 14: Návod pro prokazování a rízení kvality odběru vzorků vod a manipulace s nimi. 


\author{
Autoři \\ Ing. Jiří Kučera ${ }^{1}$ \\ 凶jiri.kucera@vuv.cz \\ Ing. Jana Čapková1 \\ 凶jana.capkova@vuv.cz \\ Ing. Alžběta Petránová \\ 凶alzbeta.petranova@vuv.cz \\ RNDr. Mgr. Petr A. Skřehot, Ph.D. ${ }^{2}$ \\ 凶skrehot@zuboz.cz \\ RNDr. Ing. Marcela Skřehotová ${ }^{3}$ \\ 凶skrehotova@ergowork.cz \\ 'Výzkumný ústav vodohospodářský T. G. Masaryka, v. v. i. \\ ${ }^{2} Z$ nalecký ústav bezpečnosti a ochrany zdraví, z. ú. \\ ${ }^{3}$ ERGOWORK s. r. o.
}

\section{WATER SAMPLING SPECIALIST \\ AND REQUIREMENTS FOR HIS PROFESSIONAL COMPETENCE}

\section{KUCERA, J.'; CAPKOVA, J.'; PETRANOVA, A. .'; SKREHOT, P. A. ${ }^{2}$; SKREHOTOVA, M. ${ }^{3}$}

'TGM Water Research Institute, p. r. i.

${ }^{2}$ Expert Institute of Safety and Health Protection ${ }^{3}$ ERGOWORK s. r. o.

Keywords: sampling - sampler - qualifications

Testing laboratory is responsible for the sampling for the purposes of the Water Act, the Water Supply and Sewerage Act and the Public Health Protection Act. Requirements for the qualification and further training of samplers are defined by the laboratory in its controlled documentation, while in the case of water sampling; the new minimum requirements are set in the standard ČSN EN ISO 5667-14. For the definition of requirements, the laboratory may use the qualification standards for the profession of drinking water sampler and the waste water sampler. The paper describes the reasons for designing new water sampling specialist profession and its qualification standard. At the same time, the documents prepared for health and safety at work for water sampling are presented. 